IN MEMORIAM 



\section{Miguel Cruz Hernández (1920-2020)}

El pasado 25 de marzo 2020 murió en Madrid Miguel Cruz Hernández; el día 15 de enero había cumplido cien años. Don Miguel, como era conocido familiarmente en los círculos académicos, nació el 15 de enero de 1920 en Málaga, donde sus padres eran maestros nacionales que después obtuvieron el traslado a Granada. Su padre enseñaba en la escuela del orfanato de Granada, y él fue también alumno del centro. En el Instituto de Granada hizo el bachillerato y aprobó el examen de estado.

En Granada, la sublevación franquista sorprendió a Miguel Cruz Hernández cumplidos sólo 16 años - en alguna ocasión nos contó la terrible experiencia de haber estado a punto de ser fusilado por los rebeldes porque pertenecía a un ateneo republicano. Pasó el resto de la guerra en zona republicana y el último año fue alistado en su ejército.

Terminada la guerra, tuvo que repetir el examen de estado; estudió Filosofía y Letras en la Universidad de Granada (1939-1943) y se doctoró por la Central (Madrid, 1947) con una tesis sobre La metafísica de Avicena. Su primera intención era dedicarse a la fenomenología y hacer su tesis sobre Franz Brentano. Las autoridades de la Universidad Central no aceptaron el tema, pero Emilio García Gómez le ayudó y fue el director de una tesis pionera en España sobre el filósofo oriental.

Afortunadamente, su juventud republicana no le perjudicó en su carrera profesional, pues fue profesor contratado en la Universidad de Granada un año después de la licenciatura (1944-1949), y, desde 1950 hasta 1976, catedrático de Filosofía y Psicología en la Facultad de Filosofía y Letras de la Universidad de Salamanca. De esta facultad fue Decano entre 1969 y 1971.

En 1976 obtuvo el traslado a la Universidad Autónoma de Madrid, como catedrático de Psicología, y en esa enseñó pensamiento islámico incluso después de la jubilación en 1987. Fue la primera vez que en una universidad española se impartía esta materia de manera independiente, y no dentro de la filosofía medieval.

Investigar en la España de posguerra era duro, por la escasez de medios y de maestros, pero Don Miguel consiguió una estancia de investigación en la Sorbona (1950-1951) con Ëtienne Gilson. En París tuvo acceso a los medios necesarios y pudo establecer relaciones personales y científicas con figuras como Jacques Maritain y Louis Massignon, del que destacaba su profundo conocimiento de la religiosidad musulmana.

Cuando se creó el Instituto Hispano-Árabe de Cultura (IHAC), fue subdirector del mismo entre 1954-1958, siendo Emilio García Gómez su director. Su afabilidad le ganaba amigos de posiciones ideológicas muy opuestas, y no es de sorprender que ocupara diversos cargos políticos durante el tardo-franquismo. Fue alcalde de Salamanca (19581962) y gobernador civil de Albacete (1962-1968). Llegó a ser Director General de Cultura 
entre 1974 y 1977, y en calidad de tal, también Presidente del Instituto del Libro Español ${ }^{1}$. Creó el premio Cervantes y suprimió la censura en los libros.

Desde 1958, Miguel Cruz Hernández era socio de la Sociedad Internacional para el Estudio de la Filosofía Medieval, y su compromiso fue decisivo para organizar el V Congreso Internacional que se celebró entre Madrid, Córdoba y Granada, los días 5-12 de septiembre de 1972 bajo el título de «Encuentro de culturas en la filosofía medieval».

Cruz Hernández era filósofo en primer lugar, y seguía la fenomenología. Esto explica su metodología, le interesaba la comprensión de las doctrinas, y no tanto los detalles. También nos ha dejado un buen número de traducciones del árabe y una del hebreo, el Compendio de la República de Platón de Averroes, publicado por la editorial Tecnos, de Madrid, el 1989, que ha llegado a la sexta edición. Gracias a su interés por el contenido y a su gran capacidad de trabajo creó obras ambiciosas como son sus historias de la filosofía islámica:

1957: Filosofía hispano-musulmana, Madrid, Asociación Española para el progreso de las ciencias.

1963: La filosofía árabe, Madrid, Revista de Occidente.

1981: Historia del pensamiento en el mundo islámico. Volumen 1. Desde los orígenes hasta el siglo XII. Volumen 2. Desde el Islam andalusí hasta el socialismo árabe. Madrid, Alianza Editorial.

Cruz Hernández fue revisando y ampliando esta obra, que se tradujo al italiano y al francés; la última edición es de la misma editorial y del año:

2012: Volumen 1. Desde los orígenes hasta el siglo XII en Oriente. Volumen 2. El pensamiento de al-Andalus (siglos IX-XIV). Volumen 3. El pensamiento islámico desde Ibn Jaldún hasta nuestros días.

Si contrastamos las diversas ediciones, desde 1957 hasta 2012, observamos una evolución en varios sentidos. Los autores y doctrinas son tratados en mayor extensión, se añaden nuevos pensadores, y se llega al periodo contemporáneo.

Don Miguel escribió una monografía sobre Averroes: Averroes, vida, obra, pensamiento, influencia, publicada en Córdoba (Cajasur, 1986, reedición 1997). En español, es la única monografía que se ocupa de todos los aspectos del pensamiento de Averroes de manera detallada.

A pesar de que el lulismo no era su línea de investigación fundamental, don Miguel participó en los congresos sobre Ramón Llull y el 1977 fue nombrado Magister de la

\footnotetext{
${ }^{1}$ Información adicional en Zanza Elío, A., «Conversación en Madrid con Miguel Cruz Hernández», Anuario de Historia de la Iglesia, 9 (2000), pp. 395-413, https://hdl.handle.net/ 10171/9238; véase también el número doble 86/87 de Anthropos. Revista de documentación científica de la cultura, Sant Cugat del Vallès, julio-agosto 1988 .
} 
Maioricensis Schola Lullistica. La Fundación March le encargó una monografía sobre Ramon Llull, que publicó la Editorial Castalia en 1977, en la colección «Pensamiento literario español», con el título El pensamiento de Ramón Llull.

Sus conocimientos abarcaban también la psicología, de la que fue profesor, siendo autor de un manual, Lecciones de psicología (Madrid, Revista de Occidente, 1976) o la historia. El islam de al-Andalus: historia y estructura de su realidad social (Madrid, Agencia Española de Cooperación Internacional, 1992). El título ya insinúa el planteamiento: estudiar el Islam en la península ibérica en la época en que el dominio era musulmán, y como realidad social. Cruz Hernández destaca la singularidad (pág. 14-17) de al-Andalus y la relaciona con el hecho de que este espacio nunca tuvo unos límites estables, sino una identidad de frontera.

Cruz Hernández reconoce que nunca fue «encantado por el al-Andalus islámico, quizás por simple reacción» (pág. 17), algo fácilmente comprensible para quien conozca la historiografía dominante. Su obra es una reflexión buscando el sentido de la estructura social del Islam andalusí. Por ejemplo, reflexiona sobre "el éxito árabe-beréber» por su rapidez y lo compara con el del general Franco en 1936 en su avance hasta Madrid a primeros de noviembre de 1936. Señala como una de las diferencias que, mientras este encontró «población propicia en la mayor parte de su trayecto», Târiq ibn Ziyâd solamente contó con «los descontentos y los judíos» (p. 69).

Don Miguel tuvo numerosos discípulos y dirigió 16 tesis doctorales pertenecientes a los diferentes ámbitos de su investigación. La larga vida que Dios le donó supo aprovecharla dedicándose a la ciencia, a los amigos y discípulos, y a una familia numerosa, que lamentan su ausencia definitiva.

Josep Puig Montada

Universidad Complutense de Madrid 
